\title{
Effect of pH and Mexican Oregano (Lippia berlandieri Schauer) Essential Oil Added to Carboxymethyl Cellulose and Starch Edible Films on Listeria monocytogenes and Staphylococcus aureus
}

\author{
Addí Rhode Navarro-Cruz ${ }^{10},{ }^{1}$ Carlos Enrique Ochoa-Velasco, ${ }^{1}$ \\ Francisco Javier Caballero-Alvarez, ${ }^{1}$ Martin Alvaro Lazcano-Hernández, ${ }^{1}$ \\ Obdulia Vera-López, ${ }^{1}$ Aurelio López-Malo ${ }^{D}{ }^{2},{ }^{2}$ and Raul Avila-Sosa $\mathbb{D D}^{1}$ \\ ${ }^{1}$ Departamento de Bioquímica-Alimentos, Facultad de Ciencias Químicas, Benemérita Universidad Autónoma de Puebla, \\ Edificio 105E, 14 Sur y Av. San Claudio, Ciudad Universitaria, Col. San Manuel, 72420 Puebla, PUE, Mexico \\ ${ }^{2}$ Departamento de Ingeniería Química, Alimentos, y Ambiental, Universidad de las Américas Puebla, 72810 Cholula, \\ PUE, Mexico
}

Correspondence should be addressed to Raul Avila-Sosa; raul.avila@correo.buap.mx

Received 19 January 2018; Revised 5 April 2018; Accepted 15 April 2018; Published 9 May 2018

Academic Editor: María B. Pérez-Gago

Copyright (C) 2018 Addí Rhode Navarro-Cruz et al. This is an open access article distributed under the Creative Commons Attribution License, which permits unrestricted use, distribution, and reproduction in any medium, provided the original work is properly cited.

\begin{abstract}
The aim of this work was to evaluate the effect of $\mathrm{pH}$ and Mexican oregano essential oil (MOEO) added to carboxymethyl cellulose (CMC) and starch (S) edible films on Listeria monocytogenes and Staphylococcus aureus. CMC and S edible films were formulated with different concentrations $(0 \%, 0.25 \%, 0.50 \%, 0.75 \%$, and $1 \%)$ of MOEO at different $\mathrm{pH}(5,6$, or 7$)$. Antimicrobial assay was performed. Inhibition curves were fitted to the Fermi model. Significant differences $(p<0.05)$ were found in $t_{\mathrm{c}}$ (time to reduce $50 \%$ of microbial population) and $a$ (slope of the curve around $t_{\mathrm{c}}$ ), being lower at acidic $\mathrm{pH}$. For L. monocytogenes, CMC films exhibited a higher antimicrobial effectiveness $(0.50 \%$ of MOEO) compared to $S$ films which need a higher concentration of MOEO (0.75\%). S. aureus was inhibited with CMC films at $0.50 \%$ MOEO and $\mathrm{pH} 5$ and 6 . Microbial modeling has allowed estimating key intrinsic factors as $\mathrm{pH}$ and $\mathrm{MOEO}$ concentration with the synergistic effect against two important food-borne pathogens.
\end{abstract}

\section{Introduction}

Researchers around the world are investigating the use of essential oils to protect food from microbial growth. The antimicrobial activity of essential oils and plant extracts is well known for a long time, and many research results have been published against food-borne pathogens [1] and about their low toxicity to mammals, fewer environmental effects, and low cost, which make them more attractive than synthetic antimicrobials [2]. Based on their traditional use, these extracts obtained from plants are first recommended, due to their broad-spectrum antimicrobial action and low side effects treatments [3]. Essential oils also have the additional effect of maintaining the quality of the food during storage, including sensorial, nutritional, and functional properties $[4,5]$.
Carvacrol (5-isopropyl-2-methylphenol) and thymol (2-isopropyl-5-methylphenol) are the major components of the essential oils of some species belonging to the Lamiaceae family including oregano, and these are phenolic compounds; isomers of monoterpenes exhibit significant antimicrobial activity in vitro [6, 7]. The WHO recognized thymol and carvacrol as GRAS compounds for consuming as long as they not exceed $50 \mathrm{mg} \cdot \mathrm{kg}^{-1}$ [6].

Natural antimicrobial compounds effectiveness depends on the type, genus, species, and strain of the target microorganism and some food intrinsic and extrinsic factors such as $\mathrm{pH}$, temperature, water content, atmospheric composition, and initial microbial load, with $\mathrm{pH}$ being one of the most important factors due to antimicrobial dissociation [3]. 
Bacterial susceptibility to essential oils increases with a reduction in food $\mathrm{pH}$, since at low $\mathrm{pH}$ the hydrophobicity of the oil increases more easily allowing the dissolution of the membrane lipids' target bacterium [8].

Currently, research has been focused on the use of edible films due to their safety regarding consumption and friendly relation with the environment, and coating materials being used currently include polysaccharides (cellulose derivatives, starch, chitin, and gums), proteins (soy, milk, gelatin, corn zein, and gluten), and lipids (oils, waxes, and resins) [9]. Among them, carboxymethyl cellulose (CMC) and starch (S) are the most widespread and economic biomaterials. In addition, its chemical, physical, and functional characteristics make them suitable to add essential oils (EOs) as antimicrobials [10-12]. Several works in the literature focus on the evaluation of the antibacterial effect of EOs and propose them as an interesting option to ensure the safety and quality of minimally processed foods and extend their shelf life [13, 14]. Moreover, there are evidences that EOs incorporated to edible films can inhibit a large variety of food-borne pathogens [13, 15-19]. The main advantage of using EOs in a polymer matrix coating is a slow diffusion of the antimicrobial agent, leaving high concentrations of the active compound in contact with the food surface where contamination has occurred or is likely to occur, for a long period [20]. The aim of this work was to evaluate the effect of $\mathrm{pH}$ and Mexican oregano essential oil concentration added to CMC and S edible films on Listeria monocytogenes and Staphylococcus aureus.

\section{Materials and Methods}

2.1. Essential Oil and Chemical Characterization. Mexican oregano (L. berlandieri Schauer) essential oil (MOEO) was provided by CiReNA (Natural Resources Research Center of Salaices, López, Chihuahua, Mexico), which was obtained by vapor distillation for $4 \mathrm{~h}$ with a Clevenger-type apparatus. MOEO was analyzed with the GC-MS (TurboMass Gold Autosystem XLTM; PerkinElmer, Norwalk, CT) with a splitless injector and an FID detector, equipped with a capillary column $(30 \mathrm{~m} \times 0.25 \mathrm{ID} \times 0.25 \mu \mathrm{m})$. Helium was used as the carrier gas for a total run time of $30 \mathrm{~min}$. The obtained spectra were compared with the respective mass spectra of pure compounds and with the mass profile of the same compounds available from the US National Institute of Standard Technology (NIST) library.

2.2. Edible Film Preparation. Films were made according to the Bertuzzi et al. [21] methodology with some modifications. High amylose corn starch (2 g) containing 75\% apparent amylose (CPI Ingredients, Mexico) or $0.5 \mathrm{~g}$ of carboxymethyl cellulose (CMC) with medium molecular weight (CPI Ingredients, Mexico) and viscosity 400-800 cP in 2 wt.\% in water $\left(25^{\circ} \mathrm{C}\right.$; Brookfield) was prepared separately in previously sterilized $10 \mathrm{ml}$ of $0.25 \mathrm{~N}$ sodium hydroxide and $10 \mathrm{ml}$ distilled water by stirring for $60 \mathrm{~min}$. Then, sorbitol (Aldrich Chemical Co., Milwaukee, WI) 0.5\% (v/v) was added as a plasticizer, and the $\mathrm{pH}$ was adjusted to 5, 6, or
7 with phosphoric acid $(1 \mathrm{~N})$. MOEO was incorporated at $0.00 \%, 0.25 \%, 0.50 \%, 0.75 \%$, or $1.00 \%(\mathrm{v} / \mathrm{v})$ final concentration. Finally, to prepare the films, $7 \mathrm{ml}$ of each solution was poured into sterile Petri dishes (60 $\mathrm{mm}$ diameter), dried $\left(0.35 \mathrm{~kg} / \mathrm{cm}^{2}\right.$ vacuum at $30^{\circ} \mathrm{C}$ for $\left.12 \mathrm{~h}\right)$, and stored in sealed Petri dishes $\left(4^{\circ} \mathrm{C}\right)$ until analysis [22].

2.3. Microbial Strains of L. monocytogenes. ATCC 7644 was provided by the Laboratorio de Salud Pública from Secretaría de Salud, Puebla, Mexico, and S. aureus ATCC 2913 was obtained from the Food Microbiology Laboratory of Universidad de las Américas Puebla. Both cultures were kept refrigerated at $5^{\circ} \mathrm{C}$ in slant tubes with Trypticase soy agar (TSA) (Merck, Mexico City, Mexico). A loopful of a stock culture was transferred to $10 \mathrm{~mL}$ of Trypticase soy broth (Merck, Mexico City, Mexico) and then incubated for $18 \mathrm{~h}$ at $35^{\circ} \mathrm{C}$.

2.4. Antimicrobial Assay. Edible films antimicrobial assays were performed according to the Sánchez-González et al. [13] methodology with some modifications. The TSA medium was poured into Petri dishes $(60 \mathrm{~mm}$ diameter $)$, and after the culture medium solidified, different edible films (55 $\mathrm{mm}$ diameter) were placed on the agar surfaces. Then, properly diluted overnight cultures $\left(10^{6} \mathrm{UFC} / \mathrm{ml}\right)$ from each strain were inoculated on every plate. Plates were incubated at $37^{\circ} \mathrm{C}$, and microbial counts on edible films were examined at $0,15,30,45,60$, and $120 \mathrm{~min}$. For this purpose, edible films ( $10 \mathrm{~g}$ ) were aseptically removed from Petri dishes and placed in sterile plastic bags with $90 \mathrm{ml}$ of saline peptone (Aldrich Chemical Co., Milwaukee, WI). Bags were homogenized for $2 \mathrm{~min}$ in a Stomacher blender (400 Circulator; Seward, United Kingdom). Serial dilutions were prepared, and then, poured TSA plates were incubated at $37^{\circ} \mathrm{C}$ for $24 \mathrm{~h}$ before colonies were counted. All tests were run in triplicate.

2.5. Modeling and Statistical Analysis. Survival curves were generated from experimental data by plotting $N / N_{0}$ (where $N$ is the number of $\mathrm{CFU} / \mathrm{mL}$ at a given time and $N_{0}$ is the initial number of $\mathrm{CFU} / \mathrm{mL}$ ) versus treatment time. Data were fitted to the Fermi model [23] from which the biological parameters $a$ and $t_{c}$ were estimated by nonlinear regression using the KaleidaGraph 3.51 program (Synergy Software, Reading, PA, USA):

$$
x=\frac{1}{\left\{1+\exp \left(t-t_{\mathrm{c}} / a\right)\right\}}
$$

where $x$ is the survival fraction $\left(N / N_{0}\right), t$ is the time (min) at which the sample was taken, $t_{c}$ is the time (min) needed to reduce $50 \%$ of microbial population, and $a$ is the slope of the curve around $t_{c}$ [24].

Fermi biological parameters were analyzed by using analysis of variance (ANOVA). Significant values were subjected to mean analysis by the least significant difference, using a significance level of $95 \%$. Statistical analyses were performed with Minitab 17 software (Minitab Inc., PA, USA, 2010). 


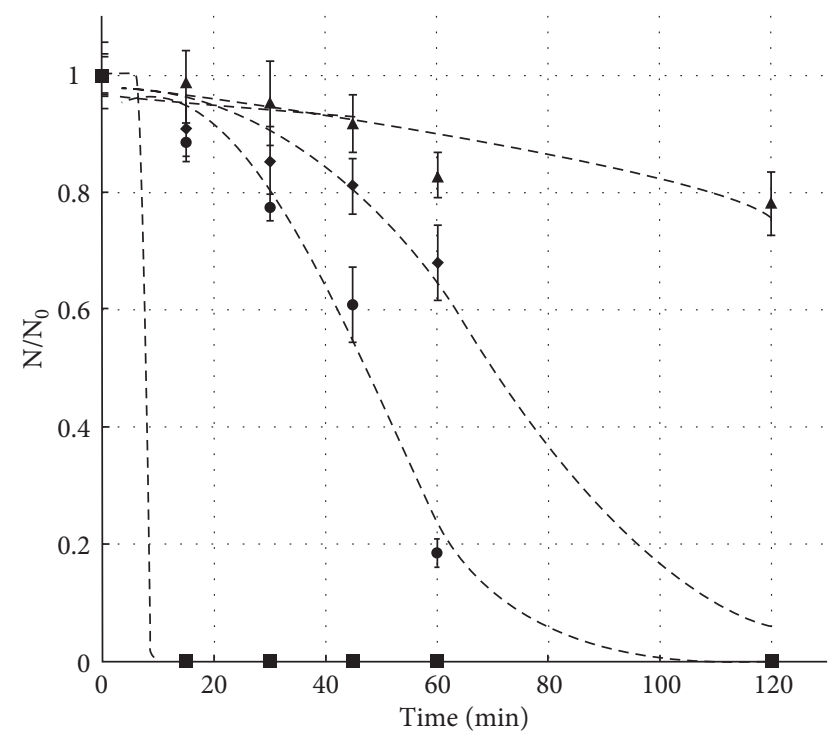

(a)

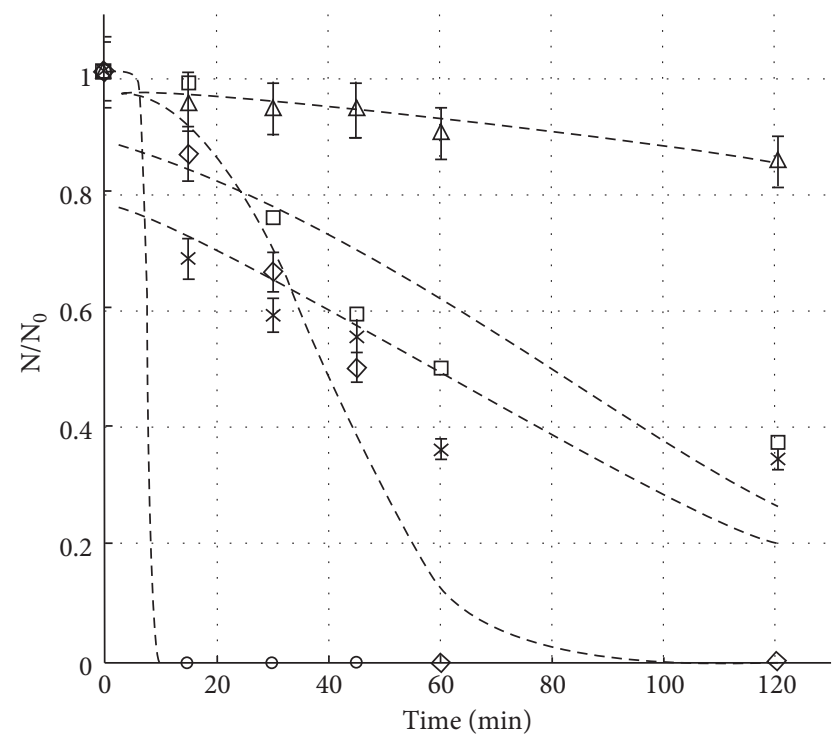

(b)

FIgURE 1: Inhibition curves of Listeria monocytogenes at different concentrations of Mexican oregano (Lippia berlandieri Schauer) essential oil and $\mathrm{pH}$ values added to CMC (a) $(0.25 \% / \mathrm{pH} 5(\square)$, $0.25 \% / \mathrm{pH} 6(\bigcirc), 0.50 \% / \mathrm{pH} 7(\boldsymbol{\Delta})$, and $0.75 \% / \mathrm{pH} 7(\bullet))$ and starch (b) $(0.25 \% / \mathrm{pH} 5(\square), 0.50 \% / \mathrm{pH} 5(\mathrm{O}), 0.50 \% / \mathrm{pH} 6(\triangle), 0.75 \% / \mathrm{pH} 6$ $(\diamond)$, and $0.75 \% / \mathrm{pH} 7(\mathrm{x}))$ edible films.

\section{Results and Discussion}

MOEO chemical analysis showed that the two major compounds were thymol $(2.452 \mathrm{~g} / \mathrm{ml})$ and carvacrol $(0.456 \mathrm{~g} / \mathrm{ml})$, whereas $p$-cymene, 1,8 -cineole, and $\gamma$-terpinen were in very low concentrations. Survival curves for both microorganisms are presented in Figures 1 and 2. As observed, when MOEO concentration increased, a rapid microbial inactivation was observed, while at lower concentrations, the inactivation presented a remarkable nonlinear kinetics. Bermúdez-Aguirre and Corradini [25] proposed that the estimation of equivalent treatments requires a proper description of the microbial

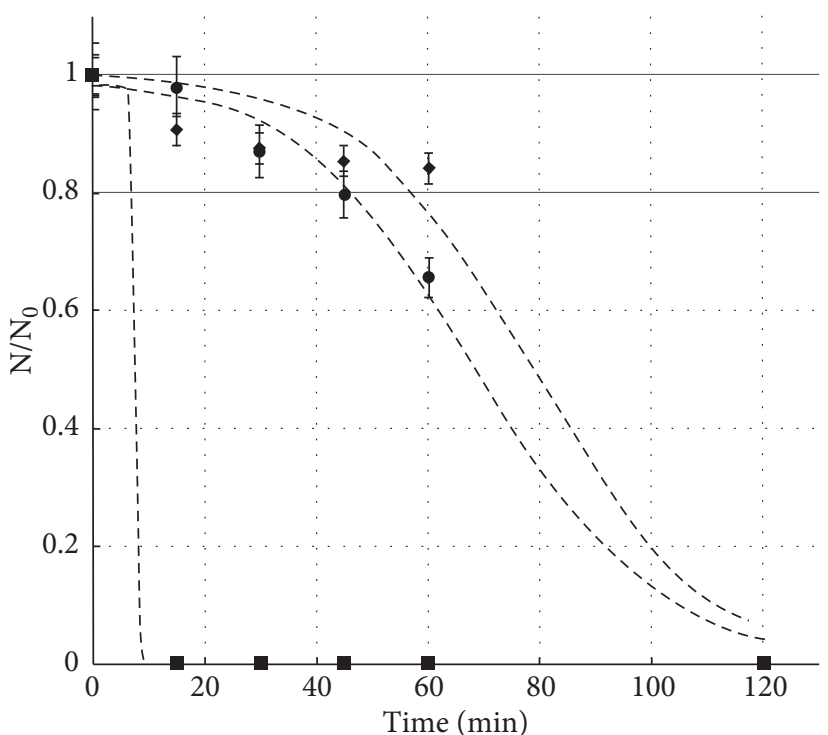

(a)

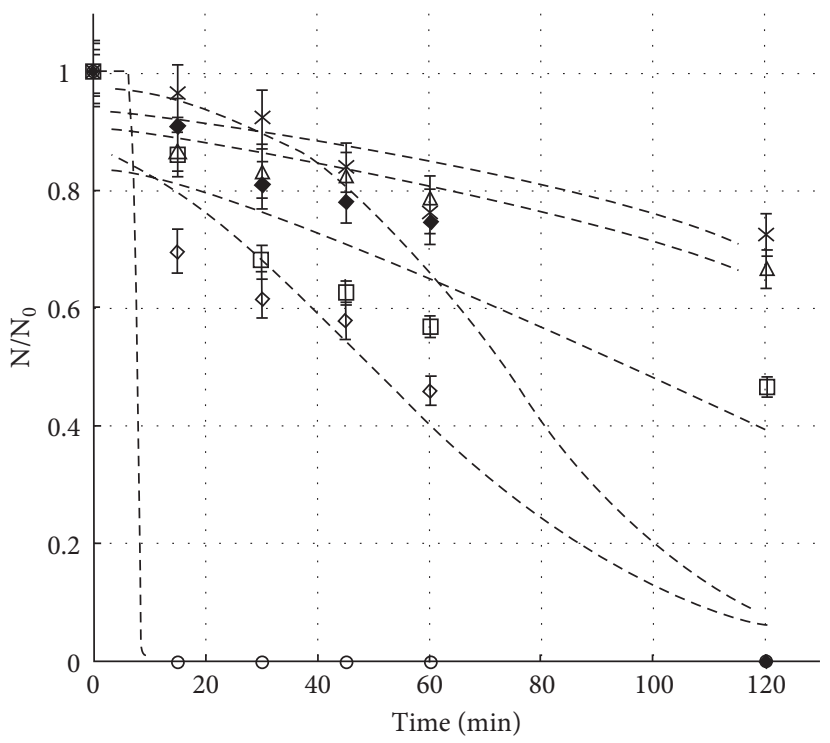

(b)

FIgURE 2: Inhibition curves of Staphylococcus aureus at different concentrations of Mexican oregano (Lippia berlandieri Schauer) essential oil and $\mathrm{pH}$ values added to CMC (a) $(0.25 \% / \mathrm{pH} 5$ ( $)$, $0.25 \% / \mathrm{pH} 6(\bullet)$, and $0.75 \% / \mathrm{pH} 7(\bullet))$ and starch (b) $(0.50 \% / \mathrm{pH} 5$ ( $\square), 0.75 \% / \mathrm{pH} 5(\bigcirc), 0.75 \% / \mathrm{pH} 6(\triangle), 1.00 \% / \mathrm{pH} 6(\diamond), 0.75 \% / \mathrm{pH}$ $7(\mathrm{x})$, and $1.00 \% / \mathrm{pH} 7(\diamond))$ edible films.

inactivation kinetics. For this reason, survival curves were adjusted with nonlinear regression using the Fermi model to predict microorganisms behavior with $R_{\text {adj }}^{2}=0.942 \pm 0.02$ and $R_{\text {adj }}^{2}=0.927 \pm 0.11$ for $L$. monocytogenes and S. aureus, respectively. This model describes a sigmoid decay and generates two biological parameters ( $a$ and $t_{\mathrm{c}}$ ) between $\mathrm{pH}$ and MOEO concentration (Table 1). Moreover, the Fermi model can explain and predict microbial reduction in all tested pathogens and is suitable to describe inactivation in similar matrices and under different operating conditions in the future [26]. Significant differences $(p<0.05)$ were found in $a$ and $t_{\mathrm{c}}$ values. Thus, lower Fermi parameters values were 
TABLE 1: Listeria monocytogenes and Staphylococcus aureus Fermi model biological parameters values at different concentrations of Mexican oregano (Lippia berlandieri Schauer) essential oil and $\mathrm{pH}$ values added to CMC and starch edible films.

\begin{tabular}{|c|c|c|c|c|c|c|}
\hline Microorganism & Film & $\mathrm{pH}$ & $\% \mathrm{EO}$ & $t_{\mathrm{c}}(\min )$ & $a$ & Fit $R_{\text {adj }}^{2}$ \\
\hline \multirow{30}{*}{ L. monocytogenes } & \multirow{15}{*}{$\mathrm{CMC}$} & 5 & 0.00 & - & - & - \\
\hline & & 5 & 0.25 & $7.59 \pm 1.94^{\mathrm{a}}$ & $0.23 \pm 0.07^{\mathrm{a}}$ & 0.992 \\
\hline & & 5 & 0.50 & $*$ & $*$ & $*$ \\
\hline & & 5 & 0.75 & $*$ & $*$ & $*$ \\
\hline & & 5 & 1.00 & $*$ & $*$ & $*$ \\
\hline & & 6 & 0.00 & - & - & - \\
\hline & & 6 & 0.25 & $46.65 \pm 8.37^{\mathrm{b}}$ & $11.61 \pm 2.09^{\mathrm{b}}$ & 0.995 \\
\hline & & 6 & 0.50 & $*$ & $*$ & $*$ \\
\hline & & 6 & 0.75 & $*$ & $*$ & $*$ \\
\hline & & 6 & 1.00 & $*$ & $*$ & $*$ \\
\hline & & 7 & 0.00 & - & - & - \\
\hline & & 7 & 0.25 & - & - & - \\
\hline & & 7 & 0.50 & $188.18 \pm 9.58^{c}$ & $58.09 \pm 5.52^{\mathrm{d}}$ & 0.886 \\
\hline & & 7 & 0.75 & $70.42 \pm 9.25^{\mathrm{d}}$ & $17.83 \pm 4.23^{\mathrm{b}}$ & 0.992 \\
\hline & & 7 & 1.00 & $*$ & $*$ & $*$ \\
\hline & \multirow{15}{*}{ Starch } & 5 & 0.00 & - & - & - \\
\hline & & 5 & 0.25 & $56.27 \pm 7.28^{\mathrm{b}}$ & $21.56 \pm 4.76^{\mathrm{c}}$ & 0.894 \\
\hline & & 5 & 0.50 & $7.59 \pm 1.94^{\mathrm{a}}$ & $0.23 \pm 0.07^{\mathrm{a}}$ & 0.992 \\
\hline & & 5 & 0.75 & $*$ & $*$ & $*$ \\
\hline & & 5 & 1.00 & $*$ & $*$ & $*$ \\
\hline & & 6 & 0.00 & - & - & - \\
\hline & & 6 & 0.25 & - & - & - \\
\hline & & 6 & 0.50 & $243.33 \pm 12.45^{\mathrm{e}}$ & $74.32 \pm 8.65^{\mathrm{a}}$ & 0.917 \\
\hline & & 6 & 0.75 & $38.48 \pm 5.78^{\mathrm{b}}$ & $10.93 \pm 2.78^{b}$ & 0.979 \\
\hline & & 6 & 1.00 & $*$ & $*$ & $*$ \\
\hline & & 7 & 0.00 & - & - & - \\
\hline & & 7 & 0.25 & - & - & - \\
\hline & & 7 & 0.50 & - & - & - \\
\hline & & 7 & 0.75 & $57.41 \pm 7.34^{\mathrm{b}}$ & $45.38+9.78^{\mathrm{d}}$ & 0.833 \\
\hline & & 7 & 1.00 & $*$ & $*$ & * \\
\hline \multirow{30}{*}{ S. aureus } & \multirow{14}{*}{$\mathrm{CMC}$} & 5 & 0.00 & - & - & - \\
\hline & & 5 & 0.25 & $9.24 \pm 2.01^{\mathrm{a}}$ & $1.29 \pm 0.01^{\mathrm{a}}$ & 0.909 \\
\hline & & 5 & 0.50 & * & $*$ & $*$ \\
\hline & & 5 & 0.75 & $*$ & $*$ & $*$ \\
\hline & & 5 & 1.00 & $*$ & $*$ & $*$ \\
\hline & & 6 & 0.00 & - & - & - \\
\hline & & 6 & 0.25 & $68.62 \pm 8.41^{\mathrm{b}}$ & $16.30 \pm 4.05^{\mathrm{b}}$ & 0.996 \\
\hline & & 6 & 0.50 & $*$ & $*$ & $*$ \\
\hline & & 6 & 0.75 & $*$ & $*$ & $*$ \\
\hline & & 6 & 1.00 & $*$ & $*$ & $*$ \\
\hline & & 7 & 0.00 & - & - & - \\
\hline & & 7 & 0.25 & - & - & - \\
\hline & & 7 & 0.50 & - & - & - \\
\hline & & 7 & 0.75 & $78.60 \pm 9.14^{b}$ & $15.11 \pm 3.48^{\mathrm{b}}$ & 0.982 \\
\hline & \multirow{16}{*}{ Starch } & 7 & 1.00 & $*$ & $*$ & $*$ \\
\hline & & 5 & 0.00 & - & - & - \\
\hline & & 5 & 0.25 & - & - & - \\
\hline & & 5 & 0.50 & - & - & - \\
\hline & & 5 & 0.75 & $95.31 \pm 11.41^{c}$ & $56.72 \pm 7.81^{\mathrm{c}}$ & 0.851 \\
\hline & & 5 & 1.00 & $9.24 \pm 2.01^{\mathrm{a}}$ & $1.29 \pm 0.01^{\mathrm{a}}$ & 0.909 \\
\hline & & 6 & 0.00 & - & - & - \\
\hline & & 6 & 0.25 & - & - & - \\
\hline & & 6 & 0.50 & - & - & - \\
\hline & & 6 & 0.75 & $163.52 \pm 19.67^{\mathrm{d}}$ & $71.16 \pm 7.87^{\mathrm{d}}$ & 0.902 \\
\hline & & 6 & 1.00 & $50.05 \pm 8.45^{\mathrm{b}}$ & $25.82 \pm 6.39^{\mathrm{b}}$ & 0.964 \\
\hline & & 7 & 0.00 & - & - & - \\
\hline & & 7 & 0.25 & - & - & - \\
\hline & & 7 & 0.50 & - & - & - \\
\hline & & 7 & 0.75 & $173.59 \pm 14.33^{\mathrm{d}}$ & $64.75 \pm 7.25^{\mathrm{c}, \mathrm{d}}$ & 0.853 \\
\hline & & 7 & 1.00 & $72.86 \pm 9.14^{\mathrm{b}}$ & $19.41 \pm 4.81^{\mathrm{b}}$ & 0.982 \\
\hline
\end{tabular}

${ }^{+} t_{\mathrm{c}}$ is the time needed to reduce $50 \%$ of microbial population; $a$ is the slope of the curve around $t_{\mathrm{c}} .-$, Growth. ${ }^{*}$ Inhibition. Means followed by a different superscript letter within a column for each concentration are significantly different $(p<0.05)$. 
obtained at $\mathrm{pH} 5$ and MOEO concentration of $0.25 \%$, suggesting that antimicrobial treatments are more effective at lower $\mathrm{pH}$ values for both microorganisms, and the $a$ value helped to evaluate bacteriostatic effects that were achieved at $\mathrm{pH} 6$ at lower MOEO concentrations. For L. monocytogenes, CMC films exhibited higher antimicrobial effectiveness than starch films at $0.50 \%$ and $0.75 \%$ MOEO at $\mathrm{pH} 5$ and 6 . S. aureus showed more resistance to edible films, that is, only for $\mathrm{CMC}$ films at $0.50 \%$ and $\mathrm{pH} 5$ and 6 . Moreover, it can be observed that, for both kinds of edible films, $\mathrm{pH}$ values of 5 and 6 are more effective than 7.

Some reports showed the antimicrobial effect of MOEO on L. monocytogenes and S. aureus with lower concentrations; however, these reports are in vitro studies and with direct application. One inconvenience of EO direct application on surfaces by dipping, powdering, or spraying is that antimicrobial compounds can be neutralized or diffuse rapidly from the surface into the product [30]. Our results demonstrate that edible films can serve as carriers releasing EO onto the surface controlling bacterial growth and reducing diffusion into the agar since the $\mathrm{EO}$ chemically forms part of the structure of the film and interacts with the polymer and the plasticizer [31]. The difference between $\mathrm{CMC}$ and starch polymers is the release of the antimicrobial compounds (mainly thymol and carvacrol) present in MOEO. In this report, the kind of polymer chain and $\mathrm{pH}$ affects the release of antimicrobial MOEO compounds due to many factors such as electrostatic interactions, osmosis, structural changes, and environmental conditions [7, 32]. Therefore, CMC releases more active compounds. $\mathrm{pH}$ is one of the most important parameters to prepare edible films since different $\mathrm{pH}$ values tend to solubilize the polymer to form the film-forming solutions [28]. However, many reports mentioned that, for proper operation of active edible films, the optimal $\mathrm{pH}$ should be considered at which the antimicrobial agent may have a state of dissociation that allows better antimicrobial activity. In this case, two main components of $\mathrm{MOEO}$ are thymol and carvacrol whose $\mathrm{pH}$ dissociation values are acidic (4.5 and 5.5, resp.) [33, 34]. Acevedo-Fani et al. [35] reported that thymol and carvacrol molecules can bind to membrane proteins of microorganisms by hydrophobic interactions. Thus, adequate $\mathrm{pH}$ values can change the membrane permeability and disintegrate the outer membrane of Gram-negative bacteria releasing lipopolysaccharides. Moreover, these authors pointed out that EO effectiveness is influenced by the sensitivity of the microorganism.

\section{Conclusion}

Microbial modeling allows estimating the effects of key intrinsic factors such as $\mathrm{pH}$ on $\mathrm{CMC}$ and starch edible films added with MOEO, showing a synergistic effect between EO concentration and $\mathrm{pH}$, so these films might have the potential to inhibit the surface growth of pathogenic microorganisms in food by being suitable carriers of EO in different food applications. Therefore, future investigations should be conducted for the application of CMC and starch as edible coatings with MOEO in food to confirm their antibacterial effect and mechanical and sensory properties.

\section{Data Availability}

The data used to support the findings of this study are available from the corresponding author upon request.

\section{Conflicts of Interest}

The authors declare that they have no conflicts of interest.

\section{Acknowledgments}

The authors acknowledge financial support from the Teacher Improvement Program (PROMEP), Mexican Ministry of Public Education (Research Project 5967).

\section{References}

[1] S. Y. Sung, L. T. Sin, T. T. Tee et al., "Antimicrobial agents for food packaging applications," Trends in Food Science and Technology, vol. 33, no. 2, pp. 110-123, 2013.

[2] N. Matan, M. Nisoa, and N. Matan, "Antibacterial activity of essential oils and their main components enhanced by atmospheric RF plasma," Food Control, vol. 39, pp. 97-99, 2014.

[3] M. S. Nabavi, A. Marchese, M. Izadi, V. Curti, M. Daglia, and S. F. Nabavi, "Plants belonging to the genus Thymus as antibacterial agents: from farm to pharmacy," Food Chemistry, vol. 173, pp. 339-347, 2015.

[4] E. L. de Souza, J. C. de Barros, C. E. V. de Oliveira, and M. L. da Conceiçao, "Influence of Origanum vulgare L. essential oil on enterotoxin production, membrane permeability and surface characteristics of Staphylococcus aureus," International Journal of Food Microbiology, vol. 137, no. 2-3, pp. 308-311, 2010

[5] M. M. Tajkarimi, S. A. Ibrahim, and D. O. Cliver, "Antimicrobial herb and spice compounds in food," Food Control, vol. 21, no. 9, pp. 1199-1218, 2010.

[6] C. O. Pérez-Alfonso, D. Martínez-Romero, P. J. Zapata, M. Serrano, D. Valero, and S. Castillo, "The effects of essential oils carvacrol and thymol on growth of Penicillium digitatum and P. italicum involved in lemon decay," International Journal of Food Microbiology, vol. 158, no. 2, pp. 101-106, 2012.

[7] M. Ramos, A. Jiménez, M. Peltzer, and M. C. Garrigós, "Characterization and antimicrobial activity studies of polypropylene films with carvacrol and thymol for active packaging," Journal of Food Engineering, vol. 109, no. 3, pp. 513-519, 2012.

[8] P. S. Negi, "Plant extracts for the control of bacterial growth: efficacy, stability and safety issues for food application," International Journal of Food Microbiology, vol. 156, no. 1, pp. 7-17, 2012.

[9] D. Sivakumar and S. Bautista-Baños, "A review on the use of essential oils for postharvest decay control and maintenance of fruit quality during storage," Crop Protection, vol. 64, pp. 27-37, 2014.

[10] I. C. Guimarães, K. C. dos Reisb, E. G. T. Menezes et al., "Cellulose microfibrillated suspension of carrots obtained by mechanical defibrillation and their application in edible starch films," Industrial Crops and Products, vol. 89, pp. 285-294, 2016.

[11] B. Ebrahimi, R. Mohammadi, M. Rouhi, A. M. Mortazavian, S. Shojaee-Aliabadi, and M. R. Koushki, "Survival of probiotic bacteria in carboxymethyl cellulose-based edible film and assessment of quality parameters," LWT Food Science and Technology, vol. 87, pp. 54-60, 2018. 
[12] V. Sessini, M. P. Arrieta, J. M. Kenny, and L. Peponi, "Processing of edible films based on nanoreinforced gelatinized starch," Polymer Degradation and Stability, vol. 132, pp. 157-168, 2016.

[13] L. Sánchez-González, M. Cháfer, M. Hernández, A. Chiralt, and C. González-Martínez, "Antimicrobial activity of polysaccharide films containing essential oils," Food Control, vol. 22, no. 8, pp. 1302-1310, 2011.

[14] A. N. Azevedo, P. R. Buarque, E. M. O. Cruz et al., "Response surface methodology for optimization of edible chitosan coating formulations incorporating essential oil against several foodborne pathogenic bacteria," Food Control, vol. 43, pp. 1-9, 2014.

[15] A. Taqi, K. A. Askar, L. Mutihaca, and I. Stamatin, "Effect of Laurus nobilis L. oil, Nigella sativa L. oil and oleic acid on the antimicrobial and physical properties of subsistence agriculture: the case of cassava/pectin based edible films," Food and Agricultural Immunology, vol. 24, no. 2, pp. 241-254, 2013.

[16] N. Tammineni, G. Ünlü, and S. C. Min, "Development of antimicrobial potato peel waste-based edible films with oregano essential oil to inhibit Listeria monocytogenes on cold-smoked salmon," International Journal of Food Science and Technology, vol. 48, no. 1, pp. 211-214, 2013.

[17] P. J. P. Espitia, R. J. Avena-Bustillos, W. X. Du et al., "Physical and antibacterial properties of açaí edible films formulated with thyme essential oil and apple skin polyphenols," Journal of Food Science, vol. 79, no. 5, pp. 903-910, 2014.

[18] R. Y. Gan, Z. Q. Deng, A. X. Yan et al., "Pigmented edible bean coats as natural sources of polyphenols with antioxidant and antibacterial effects," LWT Food Science and Technology, vol. 73, pp. 168-177, 2016.

[19] R. Navarro, C. Arancibia, M. L. Herrera, and S. Matiacevich, "Effect of type of encapsulating agent on physical properties of edible films based on alginate and thyme oil," Food and Bioproducts Processing, vol. 97, pp. 63-75, 2016.

[20] M. Kurek, A. Guinault, A. Voilley, K. Galić, and F. Debeaufort, "Effect of relative humidity on carvacrol release and permeation properties of chitosan based films and coatings," Food Chemistry, vol. 144, pp. 9-17, 2014.

[21] M. A. Bertuzzi, E. F. Castro Vidaurre, M. Armada, and J. C. Gottifredi, "Water vapor permeability of edible starch based films," Journal of Food Engineering, vol. 80, no. 3, pp. 972-978, 2007.

[22] R. Avila-Sosa, E. Hernández-Zamoran, I. López-Mendoza et al., "Fungal inactivation by Mexican oregano (Lippia berlandieri Schauer) essential oil added to amaranth, chitosan, or starch edible films," Journal of Food Science, vol. 75, no. 3, pp. 127-133, 2010.

[23] M. Peleg, "Modeling microbial populations with the original and modified versions of the continuous and discrete logistic equations," Critical Reviews in Food Science, vol. 37, no. 5, pp. 471-490, 1997.

[24] G. G. Gastélum, R. Avila-Sosa, A. López-Malo, and E. Palou, "Listeria innocua multi-target inactivation by thermosonication and vanillin," Food Bioprocess and Technology, vol. 5, no. 2, pp. 665-671, 2012.

[25] D. Bermúdez-Aguirre and M. G. Corradini, "Inactivation kinetics of Salmonella spp. under thermal and emerging treatments: a review," Food Research International, vol. 45, no. 2, pp. 700-712, 2012.

[26] J. H. Kim and S. C. Min, "Moisture vaporization-combined helium dielectric barrier discharge-cold plasma treatment for microbial decontamination of onion flakes," Food Control, vol. 84, pp. 321-329, 2018.
[27] T. Hernández, M. Canales, J. G. Avila et al., "Ethnobotany and antibacterial activity of some plants used in traditional medicine of Zapotitlán de las Salinas, Puebla (México)," Journal of Ethnopharmacology, vol. 88, no. 2-3, pp. 181-188, 2003.

[28] K.K. Kuorwel, M. J. Cran, K. Sonneveld, J. Miltz, and S. W. Bigger, "Essential oils and their principal constituents as antimicrobial agents for synthetic packaging films," Journal of Food Science, vol. 76, no. 9, pp. 164-177, 2011.

[29] M. Mendez, R. Rodríguez, J. Ruiz et al., "Antibacterial activity of plant extracts obtained with alternative organics solvents against food-borne pathogen bacteria," Industrial Crops and Products, vol. 37, no. 1, pp. 445-450, 2012.

[30] K. Marsh and B. Bugusu, "Food packaging-roles, materials, and environmental issues," Journal of Food Science, vol. 72, no. 3, pp. 39-55, 2007.

[31] A. G. Ponce, S. I. Roura, C. E. del Valle, and M. R. Moreira, "Antimicrobial and antioxidant activities of edible coatings enriched with natural plants extracts: in vitro and in vivo studies," Postharvest Biology and Technology, vol. 49, no. 2, pp. 294-300, 2008.

[32] I. Sebti, A. Martial-Gros, A. Carnet-Pantiez, S. Grelier, and V. Coma, "Chitosan polymer as bioactive coating and film against Aspergillus niger contamination," Journal of Food Science, vol. 70, no. 2, pp. 100-104, 2005.

[33] C. C. Liolios, O. Gortzi, S. Lalas, J. Tsaknis, and I. Chinou, "Liposomal incorporation of carvacrol and thymol isolated from the essential oil of Origanum dictamnus L. and in vitro antimicrobial activity," Food Chemistry, vol. 112, no. 1, pp. 77-83, 2009.

[34] C. Martínez-Graciá, C. A. González-Bermúdez, A. M. CabelleroValcárcel, M. Santaella-Pascual, and C. Frontela-Saseta, "Use of herbs and spices for food preservation: advantages and limitations," Current Opinion in Food Science, vol. 6, pp. 38-43, 2015.

[35] A. Acevedo-Fani, L. Salvia-Trujillo, M. A. Rojas-Graü, and O. Martín-Belloso, "Edible films from essential-oil-loaded nanoemulsions: physicochemical characterization and antimicrobial properties," Food Hydrocolloids, vol. 47, pp. 168177, 2015. 


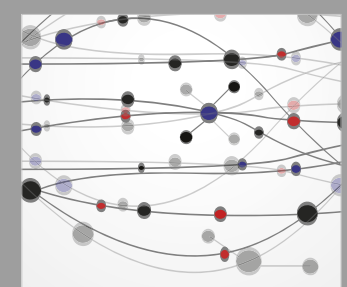

The Scientific World Journal
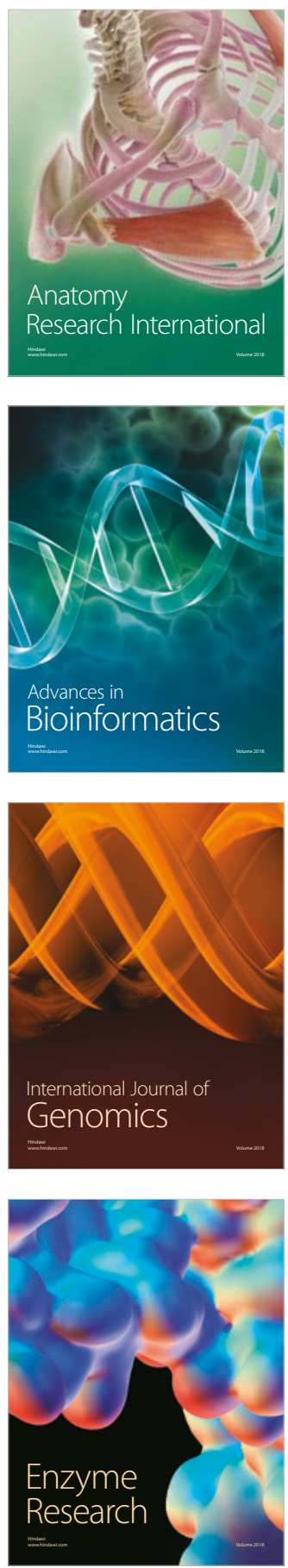
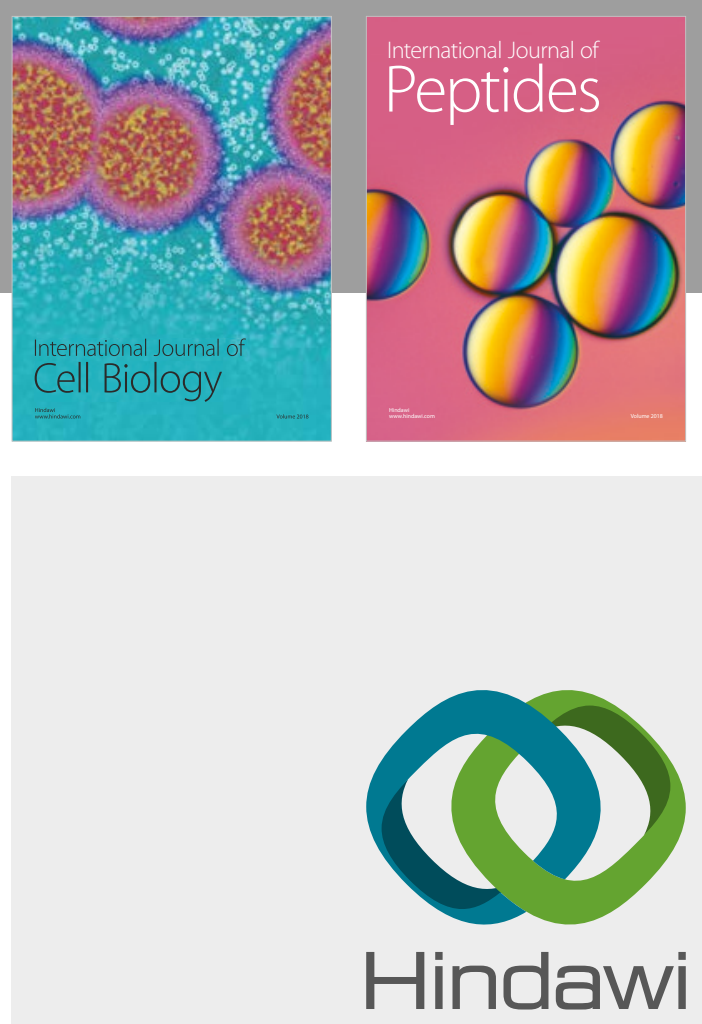

Submit your manuscripts at

www.hindawi.com
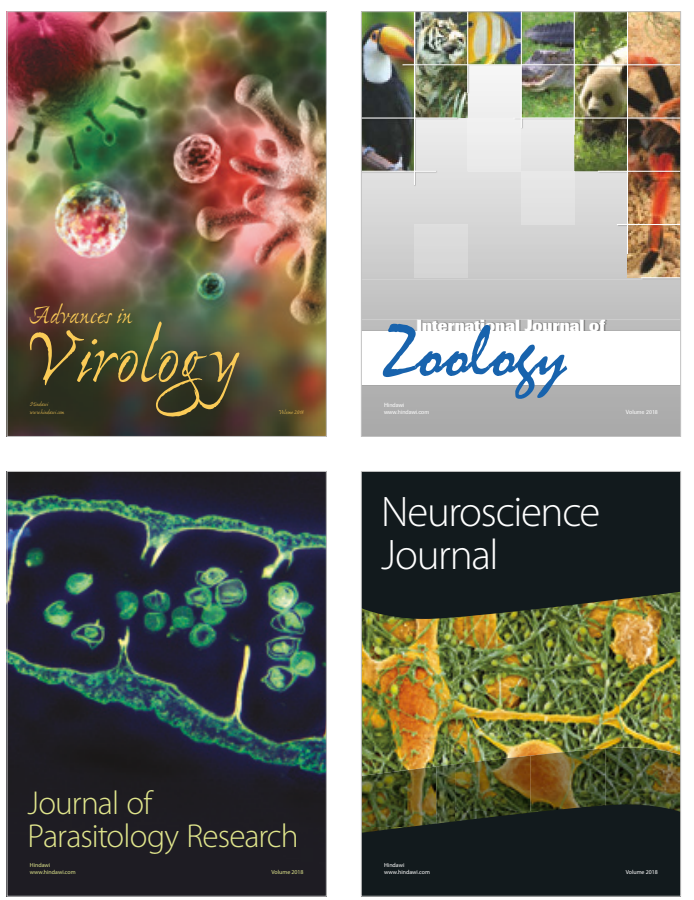
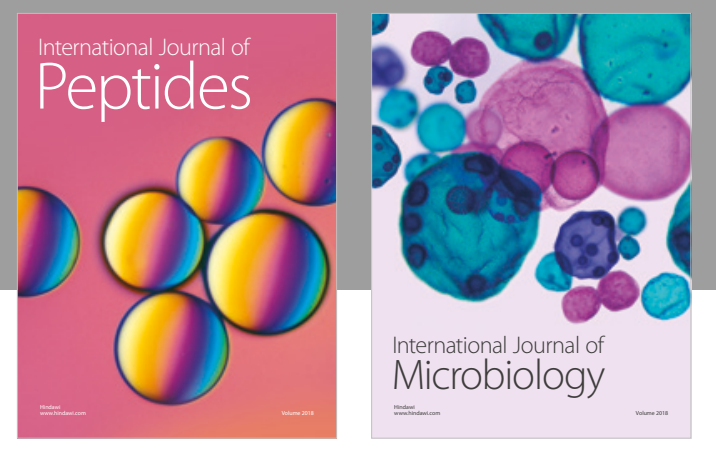

nternational Journal of Microbiology
Journal of
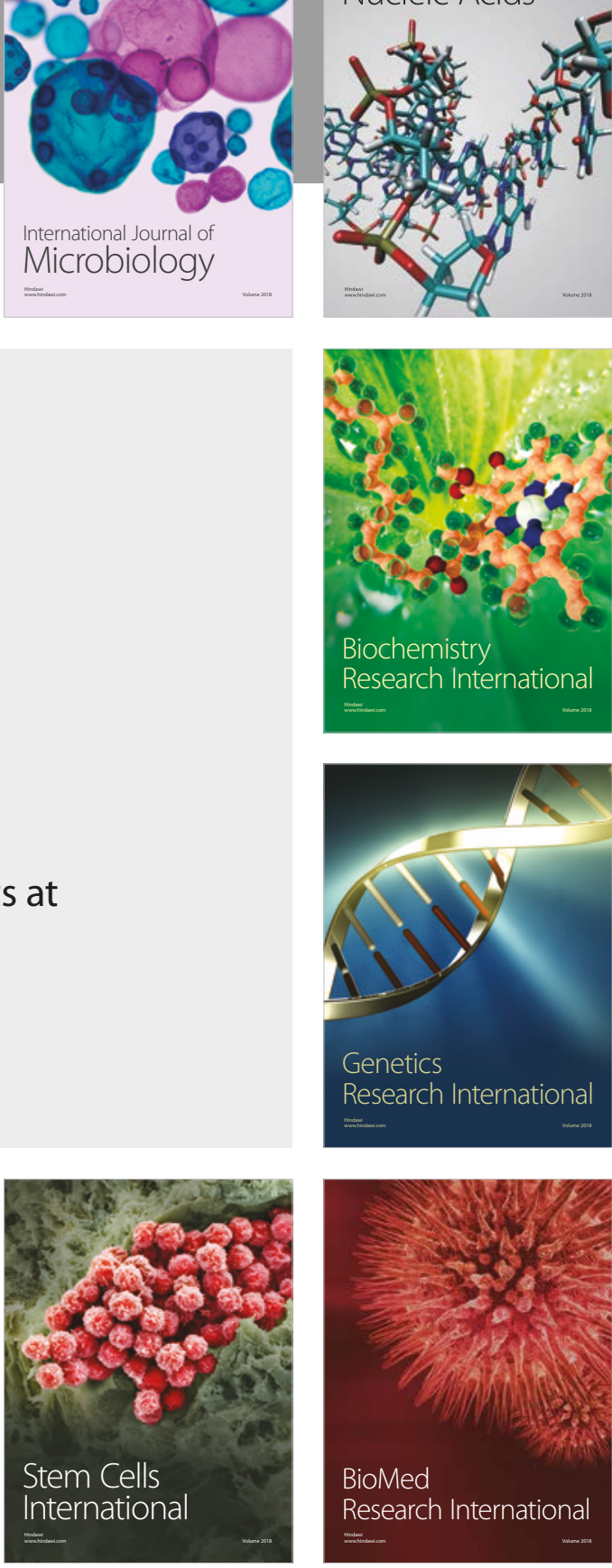
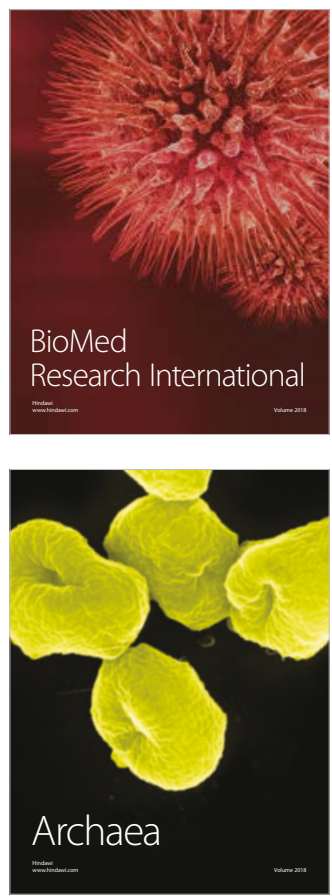